\title{
SIMILARITIES AND DIFFERENCES IN THE BINDING OF OESTRADIOL-17 $\beta$ TO RAT OVIDUCT AND UTERUS
}

\author{
K. K. SEN AND G. P. TALWAR \\ Department of Biochemistry, \\ All India Institute of Medical Sciences, \\ New Delhi 110016, India
}

(Received 27th April 1973)

A characteristic property of organs that respond to oestrogens is their ability to take up this hormone from circulation (Jensen \& Jacobson, 1962; Talwar, Segal, Evans \& Davidson, 1964; Noteboom \& Gorski, 1965; King \& Gordon, 1966; Baulieu, Alberga \& Jung, 1967; Puca \& Bresciani, 1969). The hormone is initially bound by 'receptor' proteins present in the cytoplasm, but the hormone receptor complex migrates rapidly to the nucleus (Jensen, Suzuki, Kwashima, Stumpf, Jungblut \& DeSombre, 1968; Shyamala \& Gorski, 1969). While there is extensive information on characteristics and properties of oestrogen 'receptor(s)' in the uterus, comparatively few data are available on the oviduct. Roy, Roy, Das Gupta, Engineer \& Kar (1972) have reported the uptake of this hormone in Fallopian tubes surgically removed from women post partum and those with lactational amenorrhoea. Some investigators have suggested a rôle for oestrogens in the genesis of cilia (Brenner, 1967) and in modulation of the sensitivity of the Fallopian tube to adrenergic stimuli (Coutinho \& Maia, 1970). This communication reports the similarities and differences in the binding of oestradiol-17 $\beta$ to the uterus and the oviducts in rats.

When radioactive oestradiol was given systemically to overiectomized rats, the hormone was observed to be taken up by the oviduct but to a much lower extent (about $50 \%$ on a per unit weight basis) than by the uterus. In contrast to the uterus, where the hormone was largely found in the heavy particulate (nuclear) fraction following high speed centrifugation, the subcellular distribution of the hormone was predominantly in the cytosol fraction (Table 1).

In the oviduct, oestradiol-17 $\beta$ did not undergo much metabolic change. Most of the radioactivity ( 85 to $89 \%$ ) extracted from the $600 \mathrm{~g}$ pellet and from the cytosol fraction analysed on thin-layer chromatographic plates was identified as oestradiol-17 $\beta$.

The binding of the steroid to the rat oviduct was highly discriminatory. Amongst the steroids, only oestradiol-17 $\beta$ and amongst non-steroids only diethylstilboestrol, competed with $\left[{ }^{3} \mathrm{H}\right]$ oestradiol $-17 \beta$ for binding with the cytosol fraction (Table 2). Oestradiol-17 $\alpha$, a biologically inactive stereoisomer of ostradiol-17 $\beta$, did not compete. 
The rat oviduct cytosol 'receptors' had a low dissociation constant $(K \mathrm{~d})$ for oestradiol of $4.31 \times 10^{-11} \mathrm{~mol}$ (Text-fig. 1) suggesting a high affinity for this hormone. This was of the same order as that described for rat uterine cytosol 'receptor(s)' by various workers (Toft, Shyamala \& Gorski, 1967; Shyamala \& Gorski, 1969; Puca \& Bresciani, 1969; Ellis \& Ringold, 1971).

The number of binding sites in cytosol per rat oviduct (fresh weight, 5 to $7 \mathrm{mg}$ ) was approximately $2 \times 10^{-14} \mathrm{~mol}$ or $0.33 \times 10^{-14} \mathrm{~mol} / \mathrm{mg}$ wet weight of

Table 1. Subcellular distribution of $\left[{ }^{3} \mathrm{H}\right]$ oestradiol$17 \beta$ in oviducts and uterus of ovariectomized rats

\begin{tabular}{l|c|c}
\hline \multicolumn{1}{c|}{ Fraction } & $\begin{array}{c}\text { Oviducts* } \\
\text { (\% radioactivity })\end{array}$ & $\begin{array}{c}\text { Uterus } \\
\text { (\% radioactivity })\end{array}$ \\
\hline $600-g$ pellet & $30 \cdot 0 \pm 2 \cdot 7$ & $72 \cdot 5$ \\
105,000-g pellet & $3 \cdot 0 \pm 0 \cdot 58$ & $4 \cdot 3$ \\
Cytosol & $64.9 \pm 2 \cdot 7$ & $23 \cdot 2$ \\
\hline
\end{tabular}

A dose of $10 \mu \mathrm{Ci}(0.0278 \mu \mathrm{g})$ of $\left[2,4,6,7-{ }^{3} \mathrm{H}\right]$ oestradiol$17 \beta$ in $0.1 \mathrm{ml}$ propane-1,2-diol was administered intraperitoneally to ovariectomized rats. The oviducts and uteri were removed after $60 \mathrm{~min}$ and homogenized in $0.32 \mathrm{M}$-sucrose tris-EDTA buffer (10 mM-tris-HCl, pH 7.4 and $1.5 \mathrm{~mm}$ EDTA). The homogenate was centrifuged at $600 \mathrm{~g}$ for $15 \mathrm{~min}$ and at $105,000 \mathrm{~g}$ for $75 \mathrm{~min}$. The radioactivity in the subcellular fractions was extracted with acetone, the extracts were evaporated to near dryness and counted in toluene-based scintillation fluid containing $4 \mathrm{~g}$ PPO and $0.5 \mathrm{~g}$ POPOP/litre. In a typical experiment, the total counts per min were 20,485 in uterus (131 $\mathrm{mg}$ fresh weight for both horns) and 819 in oviduct $(13 \mathrm{mg})$.

* The results are the mean \pm S.E. of nine experiments.

tissue. The number of binding sites reported by Shyamala \& Gorski (1969) in the immature rat uterus were $8.4 \times 10^{-13} \mathrm{~mol}$. As the immature rat uterus weighs aproximately 20 to $30 \mathrm{mg}$, it is surmised that the number of oestradiolbinding sites in the oviduct is approximately one-tenth of the number in the uterus. The binding sites are calculated from the initial slope of the Scatchard plot and represent sites of high affinity. The data in Tables 1 and 3, however, show that on a wet weight basis the radioactivity in the oviduct is roughly half

Table 2. Specificity of binding of oestradiol-17 $\beta$ to rat oviduct cytosol fraction

\begin{tabular}{l|c|c}
\hline \multicolumn{1}{c|}{ Treatment } & $\begin{array}{c}\text { Total bound } \\
\text { (counts/min })\end{array}$ & $\%$ bound \\
\hline Cytosol $+\left[{ }^{3} \mathrm{H}\right]$ oestradiol- $17 \beta$ & 800 & 100 \\
Cytosol +oestradiol-17 $\beta+\left[{ }^{3} \mathrm{H}\right]$ oestradiol-17 $\beta$ & 322 & $40 \cdot 2$ \\
Gytosol + diethylstilboestrol $+\left[{ }^{3} \mathrm{H}\right]$ oestradiol-17 $\beta$ & 283 & $35 \cdot 4$ \\
Gytosol +oestrone $+\left[{ }^{3} \mathrm{H}\right]$ oestradiol-17 $\beta$ & 795 & $99 \cdot 4$ \\
Gytosol +oestradiol-17 $\alpha+\left[{ }^{3} \mathrm{H}\right]$ oestradiol-17 $\beta$ & 788 & $98 \cdot 3$ \\
Gytosol + testosterone $+\left[{ }^{3} \mathrm{H}\right]$ oestradiol-17 $\beta$ & 777 & $97 \cdot 1$ \\
Cytosol + progesterone $+\left[{ }^{3} \mathrm{H}\right]$ oestradiol-17 $\beta$ & 733 & $91 \cdot 6$ \\
\hline
\end{tabular}

Aliquots $(0.2 \mathrm{ml}, 0.40 \mathrm{mg}$ protein) of rat oviduct cytosol in tris-EDTA buffer $(\mathrm{pH} \mathrm{7.4)}$ were incubated with the indicated non-radioactive steroid hormones $\left(1 \times 10^{-5} \mathrm{M}\right)$ for $15 \mathrm{~min}$; followed by $\left[2,4,6,7-{ }^{3} \mathrm{H}\right]$ oestradiol-17 $\beta$ $\left(1 \times 10^{-8} \mathrm{M}=1 \mu \mathrm{Ci}\right)$ for $60 \mathrm{~min}$ at $37^{\circ} \mathrm{C}$. A $10-\mu \mathrm{l}$ vol $(10 \mu \mathrm{g}$ approximately) of Dextran-blue was added to each tube and the incubate was passed through a Sephadex G-25 column $(1.1 \mathrm{~cm} \times 15 \mathrm{~cm})$ in the cold. The radioactivity in the protein-bound hormone eluted with the breakthrough peak was counted. 


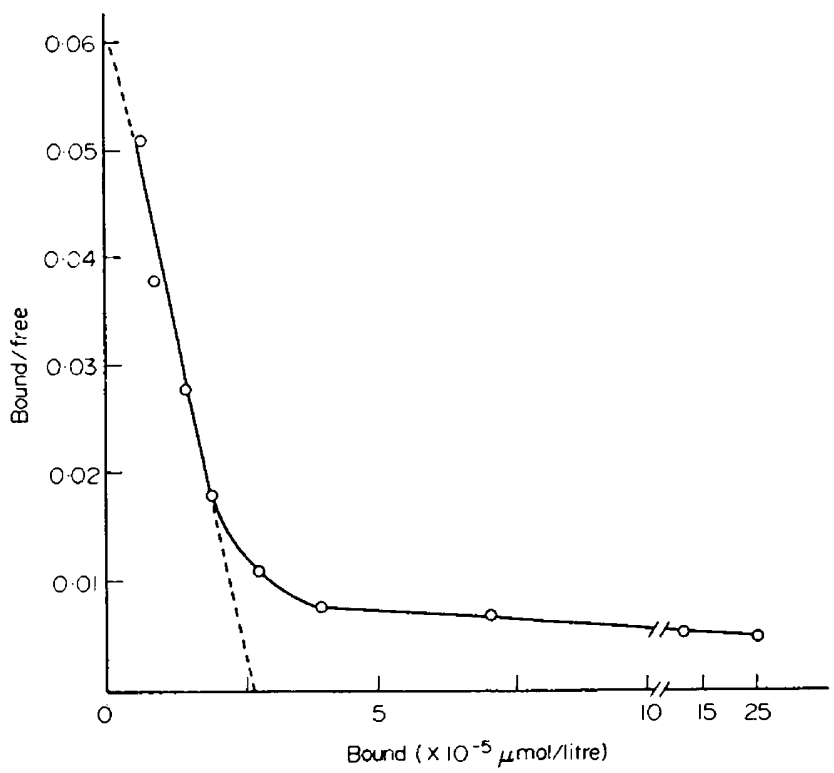

TExT-FIG. 1. Scatchard plot of the binding of oestradiol-17 $\beta$ to the cytosol fraction of rat oviduct. Aliquots $(0.2 \mathrm{ml})$ of the cytosol fraction were incubated for $60 \mathrm{~min}$ at $4^{\circ} \mathrm{C}$ in the presence of increasing concentrations of $\left[2,4,6,7-{ }^{3} \mathrm{H}\right]$ oestradiol- $17 \beta$. The bound radioactivity in each aliquot was measured by passage through a Sephadex G-25 column. $K \mathrm{~d}=4.31 \times 10^{-11} \mathrm{~mol}$.

that in the uterus. There would therefore be appreciable binding of oestrogens in the oviduct of low affinity.

The binding of oestradiol to rat oviduct 'receptors' is subject to inhibition by compounds such as 1-[2- $p(\alpha-(\mathrm{P}-$ methoxyphenyl $)-\beta$-nitrostyryl $]$ phenoxy)ethyl pyrrolidine monocitrate (CN-55, 945-27), that antagonize the binding of this hormone in the uterus (Table 3 ). In this sense, the properties of uterine and oviduct 'receptors' are similar.

These studies demonstrate the presence of 'receptors' for oestradiol in the oviduct that bind the hormone specifically and with high affinity.

Table 3. Effect of Parke Davis compound (CN-55, 945-27) on the binding of $\left[{ }^{3} \mathrm{H}\right]$ oestradiol- $17 \beta$ by rat oviduct and uterus

\begin{tabular}{|c|c|c|}
\hline \multirow{2}{*}{ Treatment } & \multicolumn{2}{|c|}{$\begin{array}{l}\text { Total tissue uptake } \\
\quad \text { (counts/min })\end{array}$} \\
\hline & Oviduct & Uterus \\
\hline $\begin{array}{l}\text { Tissue }+\left[{ }^{3} \mathrm{H}\right] \text { oestradiol-17 } \beta \\
\text { Tissue }+5 \mu \mathrm{g} \text { GN-55, } 945-27+\left[{ }^{3} \mathrm{H}\right] \text { oestradiol-17 } \\
\text { Tissue }+10 \mu \mathrm{g} \mathrm{CN}-55,945-27+\left[{ }^{3} \mathrm{H}\right] \text { oestradiol-17 } \\
\text { Tissue }+20 \mu \mathrm{g} \text { CN-55, } 945-27+\left[{ }^{3} \mathrm{H}\right] \text { oestradiol-17 }\end{array}$ & $\begin{array}{l}9114 \\
6846 \\
4834 \\
3049\end{array}$ & $\begin{array}{r}19243 \\
16560 \\
11352 \\
5240\end{array}$ \\
\hline
\end{tabular}

Minced segments (15 mg each) of oviducts and uteri collected from ovariectomized rats were incubated in the presence or absence of CN-55, 945-27 in $1 \mathrm{ml}$ Eagle's essential medium for $30 \mathrm{~min}$ at $37^{\circ} \mathrm{C}$, followed by incubation for $60 \mathrm{~min}$ at $37^{\circ} \mathrm{C}$ with $10 \mu \mathrm{Ci}(0.0278 \mu \mathrm{g})$ of $\left[2,4,6,7-{ }^{3} \mathrm{H}\right]-$ oestradiol- $17 \beta$. After washing with $0.9 \%$ saline, the tissues were homogenized and the radioactivity was extracted with acetone and measured. 
This work was supported by research grants from the World Health Organization, Geneva (Human Reproduction Division), The Ford Foundation and the Population Council Inc., New York. We are grateful to Dr Shyamala Harris and Dr J. R. Reel of Parke Davis for a gift of CN-55, 945-27.

\section{REFERENGES}

Baulieu, E. E., Alberga, A. \& Jung, I. (1967) Récepteurs hormonaux. Liaison de divers oestrogènes a des protéines uterines. Une méthode de dosage de l'oestradiol. C.r. hebd. Séanc. Acad. Sci., Paris, $\mathrm{D}, \mathbf{2 6 5}, 501$.

Brenner, R. M. (1967) Electron microscopy of estrogen effect on cytogenesis and secretory cell growth in rhesus monkey oviduct. Anat. Rec. 157, 218.

Coutinho, E. M. \& Maia, H. (1970) The influence of ovarian steroids on the response of human Fallopian tube to neurohypophyseal hormones in vivo. Am. J. Obstet. Gynec. 108, 194.

Ellis, D. J. \& Ringold, H. J. (1971) The uterine estrogen receptor. A physicochemical study. In: Biochemical Endocrinology, Vol. III, The Sex Steroids, Molecular Mechanisms. Ed. K. E. McKerns. Appleton-Century-Crofts, New York.

Jensen, E. V. \& Jacobson, H. I. (1962) Basic guides to the mechanism of estrogen action. Recent Prog. Horm. Res. 18, 387.

Jensen, E. V., Suzuki, T., Kwashima, T., Stumpf, W. E., Jungblut, P. W. \& DeSombre, E. R. (1968) A two step mechanism for the interaction of estradiol with rat uterus. Proc. natn. Acad. Sci. U.S.A. 59. 632 .

King, R. J. B. \& Gondon, J. (1966) The localization of $\left[6,7-{ }^{3} \mathrm{H}\right]$ oestradiol- $17 \beta$ in rat uterus. 7. Endocr. 34, 431 .

Noteboom, W. D. \& Gorsкi, J. (1965) Stereospecific binding of estrogens in the rat uterus. Archs Biochem. Biophys. 111, 559.

Puca, G. A. \& Bresciani, F. (1969) Association constant and specificity of estradiol binding receptor molecule. Nature, Lond. 223, 745.

Roy, S. K., Jr, Roy, S. K., Das Gupta, P. R., Engineer, A. D. \& Kar, A. B. (1972) Biochemical composition and in vitro uptake of estradiol $-17 \beta 6,7-{ }^{3} \mathrm{H}$ by the Fallopian tube - a preliminary study. Am. J. Obstet. Gynec. 112, 299.

Shyamala, G. \& Gorski, J. (1969) Estrogen receptors in the rat uterus. Studies on the interaction of cytosol and nuclear binding sites. 7. biol. Chem. 244, 1097.

Talwar, G. P., Segal, S. J., Evans, A. \& Davidson, O. W. (1964) The binding of estradiol in the uterus: a mechanism for derepression of RNA synthesis. Proc. natn. Acad. Sci. U.S.A. 52, 1059.

Toft, D., Shyamala, G. \& Gorski, J. (1967) A receptor molecule for estrogens: studies using cell free system. Proc. nallt. Acad. Sci. U.S.A. 57, 1740. 